$\underline{\text { Iranian Journal of Pathology }}$ | ISSN: 2345-3656

\title{
Dark Chocolate Intake Acutely Enhances Neutrophil Count in Peripheral Venous Blood
}

\author{
Martina Montagnana $^{\mathbf{1}}$, Elisa Danese ${ }^{\mathbf{1}}$, Gabriel Lima-Oliveira ${ }^{\mathbf{1}}$, Gian Luca Salvagno ${ }^{\mathbf{1}}$, \\ Giuseppe Lippi ${ }^{*}$
}

1. Section of Clinical Biochemistry, University of Verona, Verona, Italy

\begin{tabular}{cl}
\hline KEYWORDS & $\begin{array}{l}\text { ABSTRACT } \\
\text { Chocolate } \\
\text { Cocoa }\end{array}$ \\
$\begin{array}{c}\text { Leukocytes } \\
\text { Neutrophils } \\
\text { Infection }\end{array}$ & $\begin{array}{l}\text { Beside the well-established impact on decreasing the risk of cardiovascular } \\
\text { containing foods and the immune system (2), showing that dark chocolate } \\
\text { consumption enhances the systemic defense against bacterial (3) and viral (4) } \\
\text { infections. Hence, the current study aimed at investigating the acute effect of dark } \\
\text { chocolate intake on peripheral blood leukocytes. }\end{array}$ \\
\hline
\end{tabular}

Received 14 Oct 2016;

Accepted 28 Dec 2016;

Published Online 01 Jul 2017;

Key Words: Chocolate; Cocoa; Leukocytes; Neutrophils; Infection

Corresponding Information: Prof. Giuseppe Lippi, Section of Clinical Biochemistry,University Hospital of Verona,Piazzale LA Scuro,,37100 Verona,ITALY,E-mail: giuseppe.lippi@univr.it; ulippi@tin.it

Copyright @ 2017, IRANIAN JOURNAL OF PATHOLOGY. This is an open-access article distributed under the terms of the Creative Commons Attribution-noncommercia 4.0 International License which permits copy and redistribute the material just in noncommercial usages, provided the original work is properly cited.

\section{Dear Editor}

All participants provided an informed consent for participating in this study, which was carried out in accordance with the Declaration of Helsinki, and approved by the local ethics committee. The study population consisted of 18 consecutive healthy male volunteers $(37 \pm 10$ years), recruited from the laboratory staff, in alphabetical order. Exclusion criteria were history of hematological disorders, abnormalities of routine blood tests and signs or symptoms of disease, including weakness, cough, and fever. Each volunteer ingested $50 \mathrm{~g}$ of $90 \%$ cocoa chocolate (Noir Prodigieux, Lindt, Kilchberg, Switzerland) within 3 to 5 minutes. The nutrition information of the $50 \mathrm{~g}$ chocolate was as follows: $1242 \mathrm{~kJ}$ (i.e., $296 \mathrm{kcal}$ ), $27.5 \mathrm{~g}$ of lipids (15 $\mathrm{g}$ of saturated fat acids), $7 \mathrm{~g}$ of carbohydrates ( $3.5 \mathrm{~g}$ of sugars), and $5 \mathrm{~g}$ of proteins. Blood was drawn, immediately before chocolate intake and 4 hours after consumption, in $\mathrm{K}_{2}$ EDTA evacuated blood tubes (Vacutest Kima, Padova, Italy). All subjects accomplished 8 hours of overnight fasting before chocolate ingestion, and were then refrained from eating, drinking, and smoking for the next 4 hours after chocolate intake. White Blood Cell (WBC) count and differential count was performed using Siemens ADVIA 2120 (Siemens Healthcare Diagnostics, Tarrytown NY, USA). Differences of laboratory data before and after chocolate intake were evaluated with paired Wilcoxon's signed-rank test and Bland-Altman plots (Analyze-it Software Ltd, Leeds, UK).

The results of this study are shown in Table 1 .

A significant increase of both WBC and neutrophils counts was observed 4 hours after dark chocolate intake, whereas the other parameters of WBC remained unmodified. The Bland-Altman plot analysis revealed a mean increase of $17 \%(95 \%$ CI, $12 \%$ to $23 \%$ ) for WBC and $14 \%$ (95\% CI, $6 \%$ to $22 \%$ ) for neutrophils, respectively. 
Table 1. White Blood Cell Count and Differential Count Four Hours after Dark Chocolate Ingestion in Eighteen Ostensibly Healthy Subjects

\begin{tabular}{|c|c|c|c|}
\hline \multirow{2}{*}{ Parameter } & \multirow{2}{*}{$\begin{array}{l}\text { Baseline } \\
\quad \text { Mean } \pm \text { SD }\end{array}$} & \multicolumn{2}{|c|}{ Four hours after dark chocolate ingestion } \\
\hline & & Mean \pm SD & $\mathrm{p}$ \\
\hline White blood cells $\left(\times 10^{9} / \mathrm{L}\right)$ & $5.9 \pm 0.9$ & $7.0 \pm 0.9$ & $<0.001$ \\
\hline Neutrophils (x109/L) & $3.4 \pm 0.8$ & $3.9 \pm 0.7$ & 0.001 \\
\hline Lymphocytes (x10 $/ \mathrm{L})$ & $2.1 \pm 0.7$ & $2.3 \pm 0.5$ & 0.056 \\
\hline Monocytes $\left(\times 10^{9} / \mathrm{L}\right)$ & $0.4 \pm 0.2$ & $0.4 \pm 0.1$ & 0.379 \\
\hline Eosinophils (x109/L) & $0.2 \pm 0.2$ & $0.2 \pm 0.2$ & 0.146 \\
\hline Basophils (x109/L) & $0.1 \pm 0.1$ & $0.1 \pm 0.1$ & 0.086 \\
\hline LUC (x109/L) & $0.1 \pm 0.1$ & $0.1 \pm 0.1$ & 0.234 \\
\hline
\end{tabular}

$\mathrm{SD}$, standard deviation; LUC, Large and Unstained Cells

In conclusion, the acute effect of dark chocolate intake should be regarded as a potential source of biological (preanalytical) variability (5). Furthermore, a recent study showed that acute cocoa consumption decreases the expression of adhesion molecules (6), thus leading to reduced migration of neutrophils in peripheral tissues (including atherosclerotic plaques), which would hence contribute to reduce local inflammation, whereas their increase in the circulation may promote more efficient response against pathogens.

\section{Acknowledgements}

There was no financial support for this study.

\section{Conflict of interest}

The authors declare that there was no conflict of interest.

\section{References}

1. Lippi G, Franchini M, Montagnana M, Favaloro EJ, Guidi GC, Targher G. Dark chocolate: consumption for pleasure or therapy? J Thromb Thrombolysis 2009; 28:482-8.

2. Pérez-Cano FJ, Massot-Cladera M, Franch A, Castellote C, Castell M. The effects of cocoa on the immune system. Front Pharmacol 2013;4:71.

3. Niehues M, Stark T, Keller D, Hofmann T, Hensel A. Antiadhesion as a functional concept for prevention of pathogens: N-Phenylpropenoyl-L-amino acid amides as inhibitors of the Helicobacter pylori BabA outer membrane protein. Mol Nutr Food Res 2011;55:1104-17.

4. Kamei M, Nishimura $H$, Takahashi $T$, Takahashi N, Inokuchi K, Mato T, Takahashi K. Antiinfluenza virus effects of cocoa. J Sci Food Agric 2016;96:1150-8.

5. Simundic AM, Cornes M, Grankvist K, Lippi G, Nybo M. Standardization of collection requirements for fasting samples: for the Working Group on Preanalytical Phase (WG-PA) of the European Federation of Clinical Chemistry and Laboratory Medicine (EFLM). Clin Chim Acta 2014;432:33-7.

6. Ellinger S, Stehle P. Impact of Cocoa Consumption on Inflammation Processes-A Critical Review of Randomized Controlled Trials. Nutrients 2016;8(6). pii: E321.

\section{How to Cite This Article:}

Montagnana M, Danese E, Lima-Oliveira G, Salvagno GL, Lippi G. Dark Chocolate Intake Acutely Enhances Neutrophil Count in Peripheral Venous Blood. Iran J Pathol. 2017;12(3):311-312. 